\title{
The Analysis of U.S. Deposit Insurance System and
}

\section{the Enlightenment to China}

\author{
LIU Zhong-wen ${ }^{1,2}, Y_{U}$ Yang $^{1}$ \\ (1. College of Economic and Management, Shandong University of Science and Technology, Qingdao 266510, China; \\ 2. School of Management, China University of Mining and Technology, Xuzhou 221008, China)
}

\begin{abstract}
U.S. deposit insurance system has important and deep influence on the building and operating of the deposit insurance system for many countries in the world. Based on the analysis of the development stage and status quo of the U.S. deposit insurance system, this paper suggests that China should learn from the experience of U.S. deposit insurance system, to build and perfect the laws of deposit insurance system, and the mandatory, the scope, the insurance premium, and the top insurance amount of the deposit insurance system should be stated, and the deposit insurance agencies should maintain their independence and restrain the moral hazard. Only in that way can the deposit insurance system of China be built and perfected.
\end{abstract}

Key words: deposit insurance system; financial supervising and management; single rate; differential rate

U.S. deposit insurance system is the earliest built and the most typical one. Knowing and studying the characteristics and development tendency of U.S. deposit insurance system, learning its successful experience will be good to the building, development and perfect of Chinese U.S. deposit insurance system.

\section{The Development Stages and Status Quo of U.S. Insurance System}

Deposit insurance system refers to the kind of insurance system that the finance organizations collected together to build an insurance organization, and the deposit finance organizations are the policy holders who pay insurance premium to the insurance organization. If the policy holders run into crisis or go bankrupt, the insurance organizations will get flow cash from them, or pay the money for the depositors in some extent. U.S. is the earliest country that built the deposit insurance system and its development has gone through the two stags as follows.

\subsection{The smooth development stage before 1980s}

U.S. deposit insurance system was built during the period of the great economy depression in the $20^{\text {th }}$ century. During that time, 9755 banks were closed down and the loss amount of depositors was US\$1.4 billion, and the U.S. finance system was damaged greatly. In order to entreat the crisis, the U.S. Congress adopted a series of actions, including the announcement of some important laws and the most important one is the foundation of FDIC. FDIC is an independent organization that is responsible for the congress directly and is audited by the congress. First, the chief function of FDIC is deposit insurance. It has provided insurance for 9900 banks and 8

LIU Zhong-wen(1964- ), male, dean assistant and associate professor of College of Economic and Management, Shandong University of Science and Technology, Ph.D. candidate of School of Management, China University of Mining and Technology; research fields: economic management, capital market theory and practice.

YU Yang(1982- ), female, graduate student of College of Economic and Management, Shandong University of Science and Technology; research fields: resource economic and management, insurance. 
kinds of deposit accounts in America, and the top compensating amount is US\$100 000. About 97\% of depositors in America have accepted the insurance of FDIC. Second, FDIC has the function of bank supervising. It supervises 5616 banks and deposit credit organization. Third, FDIC has the function of treating the close down of the deposit organizations. In U.S., when the assets of the deposit organization are less than its debts and can't pay the mature debts, its management department will make decisions to close down the bank and inform FDIC.

Another thing is worthy of attention: FDIC only protects the depositors, and doesn't protect the interests of other creditors or shareholders of banks that close down. FDIC only insures the check account, deposit account, deposit receipt, retirement pension account and other deposit accounts, and doesn't insure the investment of funds, stocks, bonds or others. The top compensating amount for every depositor was only US\$2 500 in 1934 . With the increase of the income and enhancement of inflation, the top compensating amount is increased to US\$100 000 according to a law announced in 1980. In other words, the top insurance amount is US\$100 000 for the total of all the deposit accounts. But the excessive part of depositors whose insurance sum exceeds the top insurance amount can't be compensated. FDIC reminds of the depositors to be more careful before choosing banks.

Since U.S. deposit insurance system is comparative better and perfect, the rights and interests of depositors can be protect availably in this kind of insurance system, so that the objectives of protecting the rights of the depositors, making finance and economy stable can be get. Before the building of deposit insurance system in America, about 500 banks were closed down in one year on average in 1920s, the number was increased to about 2000 in 1930s and 3000 in 1933. In the early 10 years of the building of U.S. deposit insurance system, about 50 banks were closed down every year. From 1945 to 1980, about 5 banks were closed down every year on average. From the 1980s on, the number of the banks that close down increased a little, but the rate of the number to the total banks is very small. The deposit insurance system is a safe net for the whole bank system, and improves the system's credit and stabilization greatly.

\subsection{The adjustment and reform stage after the late 1980s}

There are 3 fatal defects for U.S. deposit insurance system, and these defects brought this system run into trouble directly.

First, the unsuitable pricing of deposit insurance system is easy to bring the moral problems of banks which will make FDIC face the moral hazard. Generally speaking, if investors deal with venture capital and buy the insurance for the investment, the insurance premium will increase with the increase of the venture. The higher insurance premium will limit the venture level that investors can accept by increasing the cost limitation. However, this efficient adjustment of market is blocked in the deposit insurance system-premium rate is fixed which can't form an effective price signal, and is unable to influence the venture decision-making for commercial banks in advance.

Second, the excessive protection of deposit insurance system brings the deposit market unable to limit the venture degree for the banks to accept sufficiently. The depositors don't worry about the venture of their deposit banks degree in the deposit insurance system. As long as their deposit is below the insurance amount, their money will not be damaged. Even the deposit money is over that, depositors can avoid the risk by depositing their money in different banks or opening more than one account in a same bank, so that large deposit money can be protected. Additionally, the deposit money of any large amount can't run any risk in big banks because managers of big banks will not allow the banks to be closed down for fear of influencing the credit of the whole bank system. All these safe barriers confuse the credit market, so that it is slow to act for the risks.

Third, the innovation and liberalization of finance make it possible for banks to invest in venture capital after 
1980s. The rate of venture assets of banks is increasing greatly, which is also the reason for the difficulties of the deposit insurance system.

Actually, the above defects of deposit insurance system are recognized by the finance field in U.S. So a law was announced in 1991 to shrink the scope of deposit insurance and amend some contents of the insurance premium including the change from single insurance rate to differential insurance rate which means imposing on a same deposit insurance premium. This change of insurance rate strengthened the restriction of market and reduced the moral hazard or converse choices. The top amount of deposit insurance was intended to change on the base of stabilization. The top insurance amount was US\$2 500 in 1934, and the amount was increased to US\$5 000 by the Congress rapidly and this has been kept on for 16 years. The amount was increased 5 times and was kept on for 30 years after 1950. It was increased to US\$100 000 in 1980 and to US\$130 000 after 22 years and some retirement pension accounts were increased to US\$260 000. It was stipulated that the amount should be adjusted every 5 years according to the level of inflation.

\section{The Enlightenments to the Building of Chinese Insurance System}

The changes of U.S. deposit insurance system indicate its defects, but it is also approve the importance and necessity of this system. This system can give some enlightenments to the building of Chinese deposit insurance system.

\subsection{To build and perfect laws of the deposit insurance system}

Laws of the deposit insurance system should be built and perfected, and the related system should be built as well which can protect the operating of the insurance system. In order to build the deposit insurance system in China, the related laws should be made first. The basic items should be clear in the system in China. The reforms of the system should be done in the operating, so that it can suit the change of the environment and exert its functions. Meanwhile, the related system, such as the disclosure system and social credit system, should be made.

\subsection{To state the mandatory and the scope of the deposit insurance system}

According to degree of mandatory, the deposit insurance system can be classified into three types: the forcing deposit insurance of Britain, France, Japan, Italy, Belgium, Sweden and so on; the voluntary deposit insurance of Germany and Switzerland; the combination of forcing and voluntary deposit insurance of U.S. Chinese deposit insurance system should be mandatory, the main reasons are as follows: voluntarily deposit insurance system is easier to lead to converse choices. The capital of small or middle banks is limited, so they have little passion in this system. Influenced by the planned economy in China, many banks consider the country will do something to avoid the close down of banks through their experiences.

In addition, the insured scope should be clear. Only the finance institutions with a certain credit are allowed to do the business of deposit insurance. If all the deposit finance institutions, including state-owned commercial banks, stock commercial banks, city commercial banks and so on, are allowed to do the business, the operating burden of the deposit insurance system will be heavier because the limited capital in the early period of the system. Sometimes the deposit insurance compensating organization can not bear the burden so that the government has to afford a lot of money in order to keep the order of the deposit insurance system. So the banks with excellent performance, good management and low finance venture, are first allowed to do the business in China. The four big state-owned commercial banks are included. The deposit finance organizations with big finance venture, more historical problems unsolved and heavy burden of debts can’t be included. Other deposit finance organizations 
with assets of bad quality and big finance venture will be taken into account after certain funds are solved by means of reorganizations of the organization, assets or debts. So that the people's confidence to the deposit insurance system will be improved, which will do benefit the stabilization of finance system.

\subsection{To make a rational deposit insurance premium}

The single insurance rate should be considered for Chinese deposit insurance system, and some compensation should be given to the banks with large scale and low risk. At present, there are two kinds of imposition for insurance premium, single insurance rate and differential insurance rate. There are 43 countries that use the single insurance rate now. Its advantages are: the building cost of the system is low, and it is convenient to carry out. Its disadvantages are: banks with small scale and high risk can not bear the heavy burden if all banks for different scale and different venture are imposed on a same premium; on the other hand, it is unfair and will be rejected by banks with large scale and better performance, because they think that means they will pay for banks that are in high risk. Therefore, the banks with large scale and better performance, usually refers to the four big commercial banks in China, should be compensated if the single rate is adopted.

\subsection{To give a rational top insurance amount}

Generally speaking, the deposit insurance companies only afford insurance for the current deposit, fixed deposit, saving deposit of commercial banks. The insured amount is not changeless, and it is decided by the judgment of venture, the emphasis and tendency of the policy from the finance supervising department. China should adopt the insurance ways of quota. Thought this will make the depositors with large deposit be in disadvantageous place, most people's benefits will be protected and it will warn the depositors to have the consciousness of risk adjustment. This does not mean banks will not endure any risk and the benefits of depositors will be protected completely. Of course, the decision of the top deposit insurance amount ought to indicate the significance of the insurance system. The low compensating standard can keep away moral hazard, but it also bring about bad influence to the stability of national economy, people will be suspicious to the stability of the whole national financial system and maybe they will transfer their deposits to other counties that they think to be safe. The high compensating standard means the insured rate of deposits is high, the probability of running moral hazard will be bigger, and the compensating burden of the deposit insurance organization will be heavier. Therefore, the top amount of Chinese deposit insurance ought to be decided according to the amount of the insured fund, GDP per capita, and the real income standard of residents.

\subsection{To maintain independence and keep some abilities of supervising}

The independence of the deposit insurance system is an important factor to affect the efficiency and credit of the deposit insurance organization. Most people think the more independent of the deposit insurance system, the higher of the supervising efficiency to banks and it will win more trust from people. Therefore, it should make clear the deposit insurance organizations have the right to solve the close down problems of banks. The deposit insurance organization ought to have enough authority to announce and carry out rules or regulations, adopt adjustment measures promptly, or close down banks in time by taking ways.

In addition, the deposit insurance system should have some abilities of supervising so that it can share information and cooperate with central bank in supervising, besides its more independence in the field of leaving and avoiding the governmental intervene. The relations between the deposit insurance organizations and the central banks are: (1) To maintain the liquidity of bank system commonly; (2) To supervise the bank system in common; (3) The function of the final creditor of central bank can alleviate the burden of deposit insurance company. 


\subsection{Restrain the moral hazard is the key to the operation of the deposit system}

In order to reduce the moral hazard of depositors, the way of quota compensating, which is the same meaning of making a rational insurance premium that mentioned above, should be adopted. Once the bank goes bankrupt, the deposit under compensating quota will be compensated by the insurance company, and the deposit above compensating quota will be paid after the liquidation of the bank. It is not only the embodiment of protecting depositors with small or middle deposit of deposit insurance system, but also decided by the present situation of China. Since most deposit is held by fewer people in China, only by adopting compensating quota method can the avoiding venture conscientious of depositors with large deposit can be enhanced. So that not only the benefit of most depositors with small deposit can be protected, but also the avoiding venture conscientious of depositor with large deposit can be enhanced, and the converse selection and moral hazard can be avoided.

\section{References:}

[1] YAN Hai-bo. The Difficulties and Choices during the Building of Chinese Deposit Insurance System. Finance Research, 2004(11). (in Chinese)

[2] YU Lu-lin. The International Comparison and Enlightenment of the Deposit Insurance System. Zhejiang Finance, 2006(2). (in Chinese)

[3] SU Ning. Using International Experience for Reference to Accelerate the Building of Deposit Insurance System Which Suits the Situation of China. Finance Research, 2005(12). (in Chinese)

[4] WANG Zi-li. FDIC Experiences and Problems That Should Be Paid Attention to for the Building of Chinese Deposit Insurance System. South China Finance, 2006(1). (in Chinese)

[5] HE Guang-hui. The Market Decision of Moral Hazard and Deposit Insurance Amount. Journal of Finance and Economics, 2006(1). (in Chinese)

(Edited by Jimmy Wang, Gavin Dai and Shirley Hu)

\section{(continued from Page 51)}

of Qingdao's household electrical appliances, and form the joint force of Qingdao's household electrical appliances companies, so as to create a $1+1>2$ effect, increase their whole competitiveness and attract more related industries to come to Qingdao. The specific suggestions are: because of the similarity in industry and area, on one hand, Haier can reduce its cost through purchasing together with other big household electrical appliances companies. On the other hand, Haier can set up an informal personnel resources management network. Through making use of the informal communication between the personnel and the management staff, it can build a platform where talents can have a free mobilization, and enhance the personnel resources arrangement. Besides, companies also need to increase their communication in information and technology, so as to supplement each other with their own advantages.

\section{References:}

[1] Cooke P., Hans Joachim Brazyk H.J., Heidenreich M.. Regional Innovation Systems: The Role of Governance in the Globalized Word. London: UCL Press, 1996.

[2] Porter M.E.. The Competitive Advantages of Nations. The Free Press, 1990.

[3] Porter M.E.. Clusters and New Economics of Competition. Harvard Business Review, 1998(11).

[4] WANG Bu-fang. Different Theories of Industrial Cluster. Foreign Economics and Management, 2004.

[5] XU Xiang-ren. Cluster Economy and City Economic Development. Doctor Degree Thesis of Fudan University, 1998.

[6] YIN Hong-ling. Research on the Development and the Network of Qingdao Household Electrical Appliance Cluster. Master Degree Thesis of Huadong Normal University, 2004. 